\title{
Minat dan Motivasi Berprestasi Siswa dalam Mengikuti Kegiatan Ekstrakurikuler Bolavoli
}

\author{
Bagus Pangestu $^{1 *}$, I Gusti Lanang Agung Parwata ${ }^{2}$, Made Agus Wijaya ${ }^{3}$ iD \\ ${ }^{123}$ Universitas Pendidikan Ganesha \\ *Corresponding author: Baguspangestu71@gmail.com
}

\begin{abstract}
Abstrak
Kurangnnya fasilitas yang memadai dan dukungan dari orang tua mempengaruhi minat dan motivasi berprestasi siswa dalam mengikuti kegiatan ekstrakurikuler bolavoli. Upaya mencapai prestasi yang baik maka pembinaan prestasi harus di lakukan sejak usia dini dan atlet muda berbakat sangat menentukan tercapainya prestasi atau kualitas pendidikan yang optimal dalam cabang olahraga dan bibit atlet yang unggul perlu mendapat pengelolaan yang ilmiah. Tujuan dalam penelitian ini untuk mengetahui mendeskripsikan secara faktual minat dan motivasi berprestasi siswa dalam mengikuti ekstrakurikuler bolavoli di SMP Negeri se-Kecamatan Sukasada. Rancangan penelitian yang digunakan adalah penelitian deskriptif. Populasi dalam penelitian ini adalah seluruh siswa SMP Negeri se-Kecamatan Sukasada. Data intrumen dikumpulkan dengan menggunakan metode non tes yaitu kuesioner berjumlah 20 minat dan 20 motivasi. Teknik analisis data yang akan digunakan dalam penelitian ini adalah analisis deskriptif kuantitatif dengan presentase. Hal ini menunjukan minat dan motivasi berprestasi peserta didik berpengaruh positif pada ekstrakurikuler Bolavoli di SMP Negeri se-Kecamatan Sukasada. Sampel berjumlah 67 orang yang mengikuti kegiatan ekstrakurikuler bolavoli. Hasilnya bahwa (1) minat siswa dalam mengikuti kegiatan ekstrakurikuler bolavoli di SMP Negeri se-kecamatan sukasada kabupaten buleleng tahun pelajaran 2019/2020 yaitu 10 orang $(14,9 \%)$ mempunyai minat sangat tinggi, 16 orang $(23,9 \%)$ tinggi, 22 orang $(32,8 \%)$ sedang, 19 orang $(28,4 \%)$ rendah, 0 orang $(0 \%)$ sangat rendah. (2) Motivasi berprestasi dalam mengikuti kegiatan ekstrakurikuler bolavoli di SMP Negeri se-kecamatan sukasada kabupaten buleleng tahun pelajaran 2019/2020 yaitu 11 orang $(16,4 \%)$ masuk kategori sangat tinggi, 14 orang $(20,9 \%)$ tinggi, 23 orang $(34,3 \%)$ sedang, 19 orang $(28,4 \%)$ rendah, 0 orang $(0 \%)$ sangat rendah.
\end{abstract}

Kata Kunci : Minat, Motivasi dan Ekstrakurikuler Bolavoli

\section{Abstract}

The lack of adequate facilities and support from parents affects students' interest and achievement motivation in participating in volleyball extracurricular activities. Achievement development must be carried out from an early age, and talented young athletes will determine the achievement of optimal achievement or quality of education in sports, and the seeds of superior athletes need scientific management to achieve good performance. This study aims to find out factually describe the interest and achievement motivation of students in participating in volleyball extracurricular activities in junior high schools in Sukasada. The research design used is descriptive research. The population in this study were all junior high school students in Sukasada. Instrument data were collected using a non-test method: a questionnaire consisting of 20 interests and 20 motivations. The data analysis technique that will be used in this research is quantitative descriptive analysis with percentages. It shows that students' interest and achievement motivation positively affect volleyball extracurriculars in junior high schools in Sukasada. The sample is 67 students who take part in volleyball extracurricular activities. The results are that (1) students' interest in participating in volleyball extracurricular activities at SMP in Sukasada, Buleleng for the 2019/2020 school year, 10 students $(14.9 \%)$ have very high interest, 16 students $(23.9 \%)$ are high, 22 students $(32.8 \%)$ moderate, 19 students (28.4\%) low, 0 students (0\%) very low. (2) Achievement motivation in participating in volleyball extracurricular activities at junior high school in Sukasada sub-district, Buleleng district for the 2019/2020 school year as many as 11 students (16.4\%) were in the very high category, 14 students $(20.9 \%)$ high, 23 students (34 .3\%) moderate, 19 students $(28.4 \%)$ low, 0 students $(0 \%)$ very low.

Keywords: Interest, Motivation and Volleyball Extracurricular

$\begin{array}{ll}\text { History: } & \text { Publisher: Undiksha Press } \\ \text { Received: } 03 \text { Oktober } 2021 & \text { Licensed: This work is licensed under } \\ \text { Revised: } 29 \text { Oktober } 2021 & \text { a Creative Commons Attribution 3.0 License } \\ \text { Accepted: } 01 \text { November } 2021 & \text { CC (O) OP } \\ \text { Published: } 25 \text { November } 2021 & \end{array}$




\section{Pendahuluan}

Pendidikan dan pengajaran adalah suatu proses yang sadar tujuan. Tujuan dapat diartikan sebagai suatu usaha untuk memberikan rumusan hasil yang diharapkan siswa setelah melaksanakan pengalaman belajar (Sadirman, 2004). Tercapai tidaknya tujuan pengajaran salah satunya adalah terlihat dari prestasi belajar yang diraih siswa. Dengan prestasi yang tinggi, para siswa mempunyai indikasi berpengetahuan yang baik (Hamdu, 2011). Pembelajaran itu sendiri adalah kombinasi yang tersusun meliputi unsur-unsur manusiawi, material, fasilitas, perlengkapan dan prosedur yang saling mempengaruhi untuk mencapai tujuan pembelajaran Gerry \& Kingsley dalam Snelbecker, (1980) Seperti dikutip di Sunhaji (2014), Pembelajaran di sini bukan sekedar upaya untuk memberikan pengetahuan yang beroerientasi pada target penguasan materi (siswa lebih banyak menghafal dari pada menguasai keahlian) yang diberikan gurunya, akan tetapi juga memberikan sebuah pedoman hidup yang akan dapat bermanfaat bagi dirinya dan manusia lainnya, pembelajaran juga memberikan hiburan kepada peserta didik agar bisa menjalankan aktivitas pembelajaran dengan menyenangkan bukan karena keterpakasaan di jelaskan oleh Aris Valentino, Sri Buwono (2013). Dan hasil belajar adalah perubahan tingkah laku peserta didik akibat proses kegiatan belajar mengajar, yang berupa perubahan dalam aspek kognitif, afektif dan psikomotor (Purwanto, 2009). Dijelaskan Menurut Sadiman (2010) Media pembelajaran bisa diartikan sebagai pesan, sumber, saluran, dan penerima pesan adalah komponenkomponen proses komunikasi. Pesan yang disampaikan adalah ajaran atau didikan yang ada dalam kurikulum. Sumber pesan bisa guru, siswa, buku dan media. Saluran/media yang digunaakn adalah media pembelajaran (Ngubaidillah, 2018).

Pendidikan jasmani pada dasarnya merupakan bagian integral dari sistem pendidikan secara keseluruhan, bertujuan untuk mengembangkan aspek kesehatan, kebugaran jasmani, ketrampilan berfikir kritis, stabilitas emosional, ketrampilansosial, penalaran dan tindakan moral melalui aktivitas jasmani dan olahraga. Adang Suherman dan Agus Mahendra (2002) mengemukakan bahwa pendidikan jasmani pada dasarnya merupakan pendidikan melalui aktivitas jasmani untuk mencapai perkembangan individu secara menyeluruh (Wicaksono, 2019). Pendidikan jasmani merupakan bagian yang tidak terpisahkan dari pendidikan nasional yang bertujuan untuk pengembangkan kemampuan peserta didik melalui aktivitas jasmani (Utama Bandi, 2011). Sehingga pendidikan jasmani harus diajarkan kepada setiap peserta didik pada semua jenjang pendidikan.

Perencanaan pendidikan jasmani dilakukan secara seksama untuk memenuhi perkembangan, pertumbuhan, dan kebutuhan perilaku setiap anak. Maka pendidikan jasmani bukan hanya ditujukan untuk mengembangkan kemampuan psikomotorik, akan tetapi juga mengembangkan kemampuan kognitif dan afektif peserta didik (Paramitha, 2018). Proses pendidikan tentang aktivitas jasmani, permainan atau olahraga yang terpilih untuk mencapai tujuan pendidikan. Gafur (1983) yang dikutip oleh Abdullah dan Manadji (1994:5) mengatakan tentang pendidikan jasmani sebagai berikut : Pendidikan jasmani adalah suatu proses pendidikan seseorang sebagai perorangan maupun sebagai anggota masyarakat yang dilakukan secara sadar dan sistematika melalui kegiatan jasmani yang intensif dalam rangka memperoleh peningkatan kemampuan dan keterampilan jasmani, pertumbuhan kecerdasan dan pembentukan watak (Suprayitno, 2014).

Pendidikan Jasmani yang diajarkan di sekolah memiliki peranan sangat penting, karena dapat memberikan kesempatan kepada peserta didik untuk terlibat langsung dalam berbagai pengalaman belajar melalui aktivitas jasmani yang dilakukan secara sistematis. Pembekalan Pendidikan Jasmani di sekolah diperlukan untuk memberikan kesempatan siswa dalam membina pertumbuhan fisik dan pengembangan psikis yang lebih baik, seperti yang disebutkan oleh Husdarta (2009: 3) yaitu "Pendidikan Jasmani melibatkan aktivitas fisik dan 
kesehatan untuk menghasilkan perubahan holistic dalam kualitas individu, baik dalam hal fisik, mental serta emosional" (Hasan, 2015)

Olahraga mempunyai peranan yang sangat penting dalam kehidupan sehari-hari. Dalam kehidupan modern saat ini manusia tidak dapat di pisahkan dalam kegiatan olahraga, baik untuk meningkatkan prestasi maupun untuk menjaga kesehatan kondisi tubuh agar tetap sehat. Secara umum orang memahami olahraga merupakan salah satu aktivitas yang di lakukan oleh orang, sekelompok dengan tujuan untuk menciptakan kebugaran jasmani. Aktivitas olahraga dilakukan oleh semua orang tanpa melihat perbedaan usia. Dewasa ini olahraga mendapat perhatian yang cukup besar baik untuk meningkatkan kualitas manusia dalam kesegaran jasmani maupun untuk pencapain prestasi. Salah satu tempat dimana dapat melakukan aktivitas olahraga ini di sekolah, tempat mereka belajar, dan melakukan kegiatan olahraga di luar jam sekolah yaitu melakukan kegiatan ekstrakurikuler.

Olahraga dan berolahraga merupakan hak asasi setiap orang tanpa membedakan ras, agama, kelas sosial, maupun jenis kelamin. Oleh sebab itu Komite Olahraga Internasional (IOC) sejak tahun 1983 telah mempromosikan program yang disebut dengan Sport for All, olahraga bagi seluruh masyarakat. Program ini bertujuan mendorong terwujudnya suatu kondisi di mana aktivitas olahraga dapat dilakukan oleh seluruh lapisan masyarakat, tanpa mengenal batas usia, pembedaan jenis kelamin, maupun perbedaan kondisi sosial ekonomi (Soegiyanto, 2013). Dalam perkembangan pendidikan akhir-akhir ini dapat dilihat bahwa peranan faktor psikologis dalam mencapai prestasi begitu besar. Memang tidak dapat dipungkiri bahwa prestasi belajar seorang siswa juga dipengaruhi oleh kepribadian siswa itu sendiri. Ada banyak aspek-aspek dari kepribadian yang memang sangat mempengaruhi sikap siswa dalam menghadapi suatu hal, seperti sifat-sifatnya, pikiran-pikirannya, motifnya, perasaan, kepercayaan dirinya, dan lain-lain.

Sekolah sebagai instansi yang selama ini di percaya untuk mendidik anak-anak dan remaja sebagai peran membantu remaja mengisi waktu dengan kegiatan positif, misalnya olahraga. Salah satu cabang olahraga yang digemari dikalangan masyarakat saat ini yaitu cabang olahraga bolavoli, karena olahraga ini dapat dilakukan oleh semua kalangan, baik laki-laki maupun perempuan. Dengan olahraga dapat membentuk manusia yang sehat jasmani dan rohani serta mempunyai watak disiplin dan akhirnya akan terbentuk manusia yang berkualitas. Prestasi adalah hasil atas usaha yang dilakukan seseorang dan prestasi dapat dicapai dengan mengandalkan kemampuan intelektual, emosional, dan spiritual serta ketahanan diri dalam menghadapi situasi segala aspek kehidupan. Menurut Maghfiroh (2011: 24) prestasi adalah perilaku yang berorientasi tugas yang mengijinkan prestasi individu di evaluasi menurut kriteria dari dalam maupun dari luar, melibatkan individu untuk berkompetisi dengan orang lain.

Motivasi adalah serangkaian usaha untuk menyediakan kondisi-kondisi tertentu, sehingga seseorang mau dan ingin melakukan sesuatu dan bila tidak suka maka akan berusaha untuk meniadakan atau mengelakkan perasaan tidak suka itu (Emda, 2017). Jadi motivasi dapat dirangsang oleh faktor dari luar, tetapi motivasi itu tumbuh di dalam diri seseorang. Lingkungan merupakan salah faktor dari luar yang dapat menumbuhkan motivasi dalam diri seseorang untuk belajar. Saeful (2018: 139) Motivasi adalah kondisi psikologis yang terdapat dalam diri seseorang yang mendorong pergerakan ke arah tujuan yang baik, serta mengubah tingkah laku dan persepsi agar keinginan hidupnya tercapai. Menurut Eva Latipah (2015: 158-159) motivasi adalah seseorang berbuat atau melakukan sesuatu didorong oleh sebuah kekuatan dari dalam dirinya, dorongan dari diri seseorang untuk melakukan sesuatu disebut motif, perilaku yang termotivasi adalah perilaku yang selektif, berorientasi tujuan (goal-oriented), dan dilakukan secara terus menerus (persisten).

Hubungan kesenangan dan minat merupakan sebuah hubungan yang saling mengikatkan karena kesenangan merupakan minat yang sementara. Ia berbeda dalam kualitas 
melainkan dalam ketetapan. Selama kesenangan itu ada, mungkin intensitas dan motivasi yang menyertainya sama tinggi dengan minat, namun itu akan berkurang karena kegiatan yang di lakukan hanya membei kepuasan kebutuhan yang penting dalam kehidupan seseorang. Minat dan kesenangan seorang pelajar dapat di tuangkan di dalam kegiatan sekolah yang biasa di sebut dengan kegiatan ekstrakurikuler. Dalam hal ini ekstrakurikuler juga perlu mendapat perhatian sarana dan prasarana yang di miliki sebagai penunjang meningkatkan kemampuan siswa. Minat yang dimaksud dalam hal ini adalah kegiatan olahraga yang di kembangkan di luar jam sekolah. Minat suatu rasa atau lebih suka dalam ketertarikan pada sesuatu tanpa ada yang menyuruh. Minat yang di kembangkan dalam ekstrakurikuler juga perlu adanya dukungan dan dorongan dari orang tua, budaya dan lingkungan sehingga individu siswa dapat memiliki motivasi untuk merubah minat menjadi bakat prestasi yang baik.

Permainan bolavoli merupakan cabang olahraga yang makin banyak digemari oleh masyarakat utamanya kalangan pelajar dan mahasiswa. Melalui kegiatan olahraga bolavoli ini banyak kalangan remaja memperoleh manfaat khususnya dalam pertumbuhan fisik, mental, dan sosial. Permainan bolavoli saat ini mengalami perkembangan yang pesat terbukti dengan munculnya klub-klub tangguh di tanah air dan atlet-atlet bolavoli pelajar baik di tingkat sekolah menengah pertama, menengah atas, dan perguruan tinggi. Ditunjang lagi dengan sering diadakan turnamen-turnamen, dan event-event pelajar dari tingkat daerah hingga nasional.

Ekstrakurikuler adalah kegiatan yang di selenggarakan di luar jam pelajaran sekolah yang tercantum dalam susunan program sesuai dengan keadaan dan kebutuhan sekolah. Ekstrakurikuler seperti: kesenian, pramuka, dan Olahraga. Kegiatan ekstrakurikuler yang banyak di minati oleh siswa adalah ekstrakurikuler olahraga karena kegiatan ekstrakurikuler olahraga dilakukan di luar jam pelajaran sekolah yang berguna untuk meningkatkan kualitas kesegaran jasmani siswa, karena olahraga menuntut remaja bergerak dinamis dan perilaku fisik yang bagus untuk melakukannya, selain juga penerapan nilai-nilai pengetahuan memperluas wawasan atau kemampuan olahraga untuk mencapai tujuan olahraga dan untuk mengembangkan siswa untuk mencapai sebuah prestasi olahraga yang di minatinya.

Di kecamatan Sukasada setiap sekolah tingkat SMP terdapat kegiatan ekstrakurikuler di bidang olahraga. salah satu kegiatan di bidang olahraga adalah kegiatan ekstrakurikuler bolavoli. Kegiatan ekstrakurikuler diadakan untuk mencapai prestasi dari sekolah tersebut pada suatu kompetisi olahraga tingkat pelajar antar sekolah. Dan di samping itu untuk menghasilkan bibit muda berprestasi yang nantinya akan menggantikan seniornya untuk mencapai prestasi. Di dalam permendikbud RI Nomor 81 tahun 2013 tentang implementasi kurikulum pedoman kegiatan ekstrakurikuler, pada lampiran ke III, disebutkan bahwa didalam kurikulum 2013 kegiatan ekstrakurikuler dibedakan menjadi ekstrakurikuler wajib dan kegiatan ekstrakurikuler pilihan. Kegiatan ekstrakurikuler wajib merupakan kegiatan ekstrakurikuler yang wajib di ikuti oleh seluruh siswa, kecuali siswa yang berkebutuhan khusus yang tidak memungkinkan mengikuti kegiatan ekstrakurikuler (Lampiran Permendikbud RI Nomer 81A 2013).

Dalam perkembangan voli di Indonesia kini sudah banyak klub voli. Klub voli merupakan wadah pembinaan atlet muda yang mempelajari voli, di dalamnya terjadi proses berlatih secara rutin, terencana serta mempunyai organisasi tujuan yang jelas. Selain klub voli yang merupakan wadah pembinaan atlet muda, pembinaan olahraga voli juga terdapat di ekstrakurikuler sekolah. Melalui ekstrakurikuler siswa dapat mengembangkan potensi olahraga khususnya bakat voli yang di miliki siswa. Upaya mencapai prestasi yang baik maka pembinaan prestasi harus di lakukan sejak usia dini dan atlet muda berbakat sangat menentukan tercapainya prestasi atau kualitas pendidikan yang optimal dalam cabang olahraga dan bibit atlet yang unggul perlu mendapat pengelolaan yang ilmiah. Upaya yang 
dilakukan untuk mengembangkan bakat yang dimiliki siswa-siswi yang di perlukan pembinaan olahraga, hal ini dapat dilakukan melalui kegiatan ekstrakurikuler.

Banyak faktor yang dapat mempengaruhi motivasi seorang anak untuk bermain voli baik itu faktor yang berasal dari dalam diri sendiri seperti emosi, rasa senang, perhatian dan sebagainya dan faktor yang timbul dari luar seperti orang tua, lingkungan, pengaruh teman, fasilitas, guru/pelatih atau pengaruh menonton pertandingan voli. Namun sebagian besar kendala yang sering muncul adalah kurangnnya fasilitas yang memadai dan dukungan dari orang tua. Mengatasi kesenjangan yang terjadi seperti yang telah di utarakan di atas, maka penulis ingin meneliti fenomena-fenomena yang terjadi tersebut dalam suatu penelitian. Melihat survei awal peneliti lebih berhati hati dalam menentukan tema yang sesuai dengan situasi di sekolah sehingga sehingga peneliti tidak terlalu fatal. Dengan dasar pemikiran tersebut maka peneliti menyusun penelitian yang diberi judul "Minat dan Motivasi Berprestasi Siswa dalam Mengikuti Ekstrakurikuler Bolavoli di SMP Negeri se-Kecamatan Sukasada Kabupaten Buleleng Tahun Pelajaran 2019/2020”.

\section{Metode}

Penelitian deskriptif adalah penelitian yang menggambarkan dan mendeskripsikan mengenai fenomena yang terjadi berdasarkan masalah yang ada dapat berupa deskriptif maupun berifat angka dalam pengolahan datanya. Tempat penelitian ini adalah di seluruh SMP Negeri se-Kecamatan Sukasada Kabupaten Buleleng Tahun Pelajaran 2019/2020. Populasi dalam penelitian adalah peserta didik SMP Negeri se-Kecamatan Sukasada Kabupaten Buleleng. Sampel dalam penelitian ini adalah seluruh siswa SMP Negeri seKecamatan Sukasada Kabupaten Buleleng yang mengikuti kegiatan ekstrakurikuler bolavoli baik laki-laki maupun perempuan. Pada penelitian ini, data diperoleh dengan menggunakan dokumen dan angket. Dokumen yang dikumpulkan berupa foto yang nantinya akan digunakan sebagai bukti bahwa benar melakukan penelitian. kuesioner yang disajikan dalam bentuk pertanyaan yang jawabannya telah disediakan, sehingga responden tinggal memilih jawaban yang telah disediakan oleh peneliti.

Penelitian akan dianalisis menggunakan teknik deskriptif dengan persentase, yaitu data dari angket yang berhasil dikumpulkan kemudiaan dianalisis dengan menggunakan presentase. Analisa tersebut untuk mengetahui minat dan motivasi berprestasi peserta didik pada ekstrakurikuler Bolavoli di SMP Negeri se-Kecamatan Sukasada. Instrumen yang digunakan berupa angket terdiri dari pernyataan positif dan negative. Tingkat kesetujuan responden diklasifikasikan sebagai berikut: Sangat Setuju (SS), Setuju (S), Tidak Setuju (TS), dan Sangat Tidak Setuju (STS). Agar data yang diperoleh dalam penelitian ini berupa data kuantitatif, maka setiap butir jawaban diberi skor dalam bentuk skala Likert.

\section{Hasil dan Pembahasan}

1) Minat Siswa SMP Negeri Se-Kecamatan Sukasada pada Ekstrakurikuler Bolavoli

Penelitian ini bertujuan untuk mengetahui seberapa besar minat siswa SMP Negeri Se-Kecamatan Sukasada Kabupaten Buleleng Tahun Pelajaran 2019/2020 terhadap ekstrakurikuler Bolavoli. Pengambilan data menggunakan angket. Analisis data dilakukan secara deskriptif kuantitatif. Hasil analisis deskriptif kuantitatif menunjukkan bahwa minat siswa SMP Negeri Se-Kecamatan Sukasada terhadap ekstrakurikuler Bolavoli dalam kategori sedang yaitu sebesar $32.8 \%$. Hasil ini menunjukkan bahwa ekstrakurikuler sudah menjadi ekstrakurikuler yang peminatnya banyak di kalangan siswa karena olahraga Bolavoli sangat mudah dimainkan dan merupakan olahraga yang praktis dan menyenangkan. 
Minat adalah rasa lebih suka dan rasa keterikatan pada suatu hal atau aktivitas, tanpa ada yang menyuruh". Sedangkan menurut (Djaali, 2015), "minat pada dasarnya adalah penerimaan akan suatu hubungan antara diri sendiri dengan sesuatu di luar diri”. Selanjutnya menurut Crow and Crow dalam (Djaali, 2015), "minat berhubungan dengan gaya gerak yang mendorong seseorang untuk menghadapi atau berurusan dengan orang, benda, kegiatan, pengalaman yang dirangsang oleh kegiatan itu sendiri". Menurut Suryosubroto dalam Puspayanti (2017: 53) minat kecenderungan dalam diri individu untuk tertarik pada subyek atau menyenangi suatu objek. Hal ini menunjukkan bahwa seberapa besar minat siswa dalam mengikuti kegiatan esktrakurikuler bolavoli merupakan cerminan seberapa besar peserta didik tertarik terhadap kegiatan ekstrakurikuler bolavoli. Keadaan ini dapat dipengaruhi oleh faktor dari dalam maupun dari luar. Minat peserta didik yang tinggi akan tercermin dengan tingkat partisipasi peserta didik dalam kegiatan ekstrakurikuler bolavoli yang tinggi. Sebaliknya jika minat peserta didik rendah maka dapat tercermin dalam partisipasi peserta didik dalam kegiatan ekstrakurikuler bolavoli yang rendah.

Ekstrakurikuler merupakaan ekstrakurikuler yang sudah berkembang. Sehingga pengetahuan mengenai ekstrakurikuler sangat luas. Olahraga bolavoli merupakan salah satu cabang olahraga yang sudah populer di kalangan pelajar. Minat peserta didik yang dimiliki siswa dalam melakukan olahraga bolavoli dapat dijadikan sebagai ukuran tingkat keseriusan siswa dalam mengikuti ekstrakurikuler bolavoli. Minat yang dimiliki peserta didik dipengaruhi oleh faktor yang berasal dari dalam diri ataupun luar diri mahaPeserta didik. Minat dari dalam diri individu disebut juga minat intrinsik. Aditya romantika dalam Akbar (2012: 58), menyebutkan faktor intrinsik adalah sesuatu yang membuat seseorang berminat yang datangnya dari dalam diri. Faktor Intrinsik dalam penelitian ini adalah rasa perhatian/tertarik, perhatian, perasaan senang, aktivitas Minat juga dipengaruhi oleh faktor dari luar diri Peserta didik atau sering disebut dengan faktorekstrinsik.

\section{2) Motivasi Berprestasi Siswa SMP Negeri Se-Kecamatan Sukasada pada Ekstrakurikuler Bolavoli}

Penelitian ini bertujuan untuk mengetahui seberapa besar motivasi siswa SMP Negeri Se-Kecamatan Sukasada Kabupaten Buleleng Tahun pelajaran 2019/2020 terhadap ekstrakurikuler bolavoli. Pengambilan data menggunakan angket. Analisis data dilakukan secara deskriptif kuantitatif. Hasil analisis deskriptif kuantitatif menunjukkan bahwa motivasi siswa SMP Negeri Se-Kecamatan Sukasada terhadap ekstrakurikuler bolavoli dalam kategori sedang yaitu sebesar $34,3 \%$. Hasil ini menunjukkan bahwa motivasi dari siswa yang mengikuti ektrakurikuler bolavoli sudah banyak. Hal ini disebabkan oleh fasilitas di sekolah yang memadai selain itu adanya alat atau sarana bolavoli.

Motivasi adalah seseorang berbuat atau melakukan sesuatu didorong oleh sebuah kekuatan dari dalam dirinya, dorongan dari diri seseorang untuk melakukan sesuatu disebut motif, perilaku yang termotivasi adalah perilaku yang selektif, berorientasi tujuan (goaloriented), dan dilakukan secara terus menerus (Latipah, 2012)

Motivasi memiliki kecenderungan bahwa motivasi adalah yang mendukung dan melatarbelakangi Peserta didik dalam mengikuti kegiatan ekstrakurikuler. Motivasi menurut Hamzah Uno dalam Fauziatun (2014: 11) "Motivasi merupakan dorongan yang timbul oleh adanya rangsangan dari dalam maupun dari luar sehingga seseorang berkeinginan untuk mengadakan perubahan tingkah laku/aktivitas tertentu lebih baik dari keadaan sebelumnya.

Pengertian yang dikemukakan oleh Mc. Donald ini mengandung tigaelement penting,yaitu: (1) Bahwa motivasi itu mengawali terjadinya perubahan energi pada diri setiap individu manusia. Perkembangan motivasi akan membawa akan membawa beberapa perubahan energi didalam sistem "neurophysiological" yang ada pada organisme manusia. (2) motivasi ditandai dengan munculnya rasa "feeling", afeksi seseorang dalam hal ini 
motivasi relevan dengan persoalan-persoalan kejiwaan, afeksi dan emosi yang dapat menentukan tingkah laku manusia. (3) motivasi akan dirangsang karena adanya tujuan. Motivasi memang muncul dari dalam diri manusia, tetapi kemunculannya terangsang/terdorong oleh adanya unsur lain, dalam hal ini adalah tujuan.Tujuan ini akan menyangkut soal kebutuhan.

Faktor dari manapun mampu mempengaruhi siswa untuk mengikuti kegiatan ekstrakurikuler bolavoli. Selain Peserta didik memiliki bakat dan keterampilan yang baik, Peserta didik juga ingin mengukir prestasi kegiatan ekstrakurikuler. Hal ini dikarenakan kegiatan ekstrakurikuler merupakan kegiatan yang memfasilitasi siswa untuk meningkatkan kemampuan dan keterampilan bermainnya. Dengan adanya dorongan dari kegiatan ekstrakurikuler ini akan membantu siswa untuk mencapai tujuannya dalam berolahraga.

\section{Simpulan}

Simpulan berdasarkan penelitian pada minat dan motivasi berprestasi siswa pada ekstrakurikuler bolavoli di SMP Negeri se-Kecamatan Sukasada tahun pelajaran 2019/2020 adalah pertama, minat siswa pada ekstrakurikuler bolavoli di SMP Negeri se-Kecamatan Sukasada tahun pelajaran 2019/2020 yaitu 10 siswa (14,9\%) mempunyai minat yang sangat tinggi terhadap ekstrakurikuler bolavoli, 16 siswa (23.9\%) masuk kategori tinggi, 22 siswa (32.8\%) masuk kategori sedang, 19 siswa (28.4\%) masuk kategori rendah, dan 0 siswa (0\%) masuk dalam kategori sangat rendah. dua, motivasi berprestasi siswa pada ekstrakurikuler bolavoli di SMP Negeri se-Kecamatan Sukasada tahun pelajaran 2019/2020 yaitu 11 Siswa $(16,4 \%)$ mempunyai motivasi yang sangat tinggi terhadap ekstrakurikuler bolavoli, 14 siswa $(20,9 \%)$ masuk kategori tinggi, 23 siswa $(34,3 \%)$ masuk kategori sedang, 19 siswa $(28,4 \%)$ masuk kategori rendah, dan 0 siswa $(0 \%)$ masuk dalam kategori sangat rendah.

Berdasarkan kesimpulan penelitian di atas, saran yang dapat diberikan adalah pertama, bagi peserta didik menjadi masukan sekaligus memacu semangat belajar peserta didik untuk mengembangkan diri dalam bidang olahraga sehingga dapat meningkatkan kesegaran jasmani, meningkatkan keterampilan bermain dan dapat berprestasi. dua, bagi sekolah adalah sekolah diharapkan mampu memfasilitasi kegiatan ekstrakurikuler secara maksimal agar tujuan dapat tercapai dengan maksimal.Sekolah diharapkan mampu menumbuhkan minat dan motivasi siswa dengan meningkatkan faktor-faktor yang mempengaruhi minat dan motivasi peserta didik dalam berlatih. tiga, bagi peneliti selanjutnya diharapkan peneliti selanjutnya mampu melakukan penelitian pada populasi yang lebih besar dan dengan variable yang lebih beragam, dan instrumen yang lebih baik lagi. Sehingga di harapkan penelitian akan lebih maksimal.

\section{Daftar Pustaka}

Djaali. (2015). Psikologi Pendidikan. PT Bumi Aksara.

Emda, A. (2017). Kedudukan Motivasi Belajar Siswa Dalam Pembelajaran. Lantanida Journal, 5(2), 93-196.

Hamdu, G. (2011). Pengaruh Motivasi Belajar Siswa Terhadap Pestasi Belajar IPA Di Sekolah Dasar. Jurnal Penelitian Pendidikan, 12(1).

Hasan, S. (2015). Pengembangan Model Permainan Gerak Dasar Lempar Untuk Siswa Kelas V Sdn Tawangargo 4 Karangploso Malang. Jurnal Pendidikan Olahraga, 4(2).

Latipah, E. (2012). Pengantar Psikologi Pendidikan. PT. Pusaka Intan Madani.

Ngubaidillah, A. (2018). Pengaruh Media Visual Menggunakan Aplikasi Lectora Inspire 
Terhadap Hasil Belajar Peserta Didik. Jurnal Penelitian Pendidikan, 35(2).

Paramitha, S. T. (2018). Revitalisasi Pendidikan Jasmani untuk Anak Usia Dini melalui Penerapan Model Bermain Edukatif Berbasis Alam. Urnal Pendidikan Jasmani Dan Olahraga JPJO, 3(1), 41-51.

Soegiyanto. (2013). Keikutsertaan Masyarakat dalam Kegiatan Olahraga. Jurnal Media Ilmu Keolahragaan Indonesia, 3(1).

Suprayitno. (2014). Peran Permainan Tradisional Dalam Membantu Pertumbuhan Dan Perkembangan Gerak Anak Secara Menyeluruh. Jurnal Ilmu Keolahragaan, 13(2), 715.

Wicaksono, G. H. (2019). Kreativitas Guru Penjas Terhadap Proses Pembelajaran Penjas Di Sekolah Menengah Pertama Negeri Sekecamatan Kebumen Kabupaten Kebumen 2018. Jurnal Pendidikan Kesehatan Rekreasi, 5(2), 95-100. 